Image In...

\title{
A rare case of a ball and socket ankle joint
}

\author{
Roland Fernandes \\ Orthopaedic Department, Medway Maritime Hospital, Kent, UK \\ Correspondence to Roland Fernandes, rfernandes@doctors.org.uk
}

\section{DESCRIPTION}

A 50-year-old otherwise well gentleman presented with mild pain and stiffness in his right ankle. Remarkably, radiographs revealed gross congenital deformities. The ankle mortice was semicircular and the subtalar joints fused (figure 1). There were only three metatarsals. The bases of the proximal phalanges of the first and second toes were fused and articulated with the head of the first metatarsal (figure 2). The ball and socket ankle joint was first described in English literature by Lamb in 1958. ${ }^{1}$ The aetiology of this abnormality is most often congenital but can be acquired due to poliomyelitis or

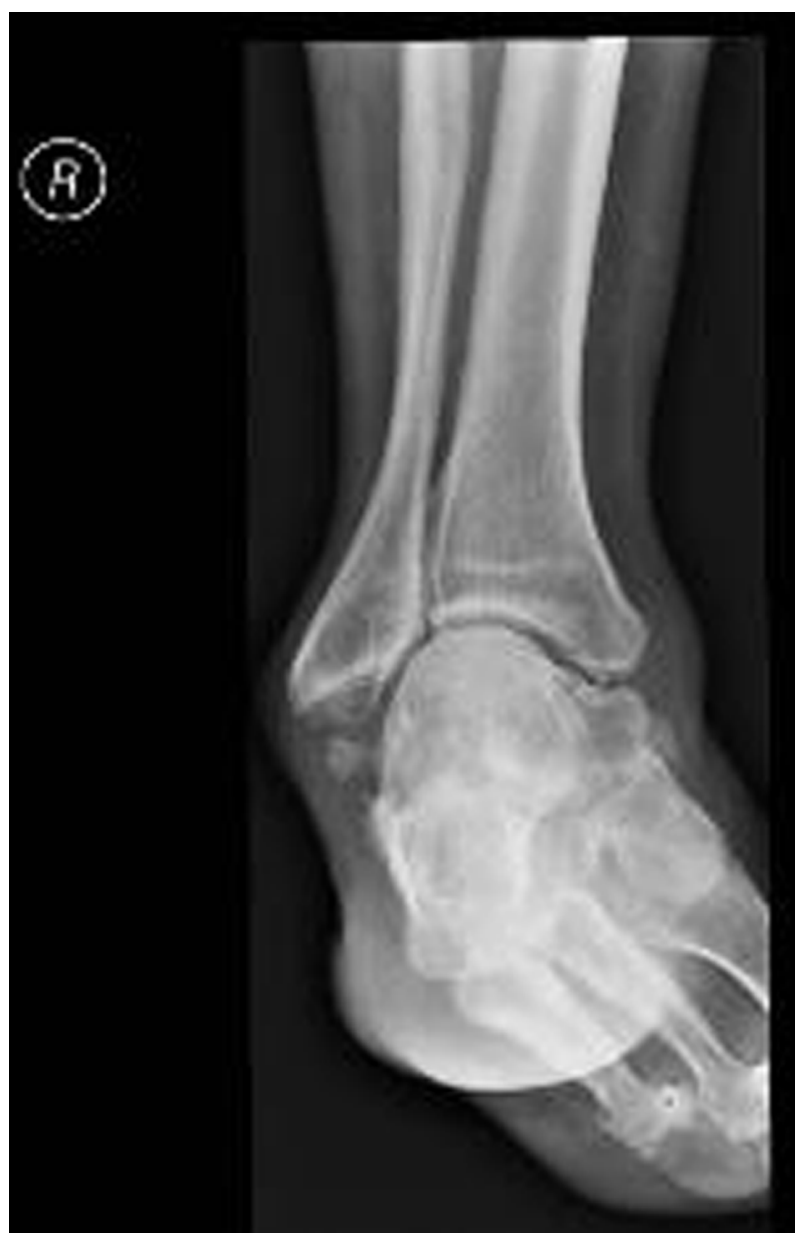

Figure 1 Radiograph of ankle joint. postsubtalar arthrodesis. ${ }^{2}$ It is most often found in association with other congenital deformities which can result in leg length discrepancy, instability, pain and stiffness. However, the reports suggest although the aforementioned symptoms can occur, what is surprising is the lack of symptoms that can occur with this malformation. The patient had mild stiffness and pain which did not impact upon his lifestyle. On examination, he had a $2 \mathrm{~cm}$ leg length discrepancy, which the authors treated with an orthotic supplement. The possible future operative interventions include fusion of the ankle joint should his symptoms progress to be more debilitating.

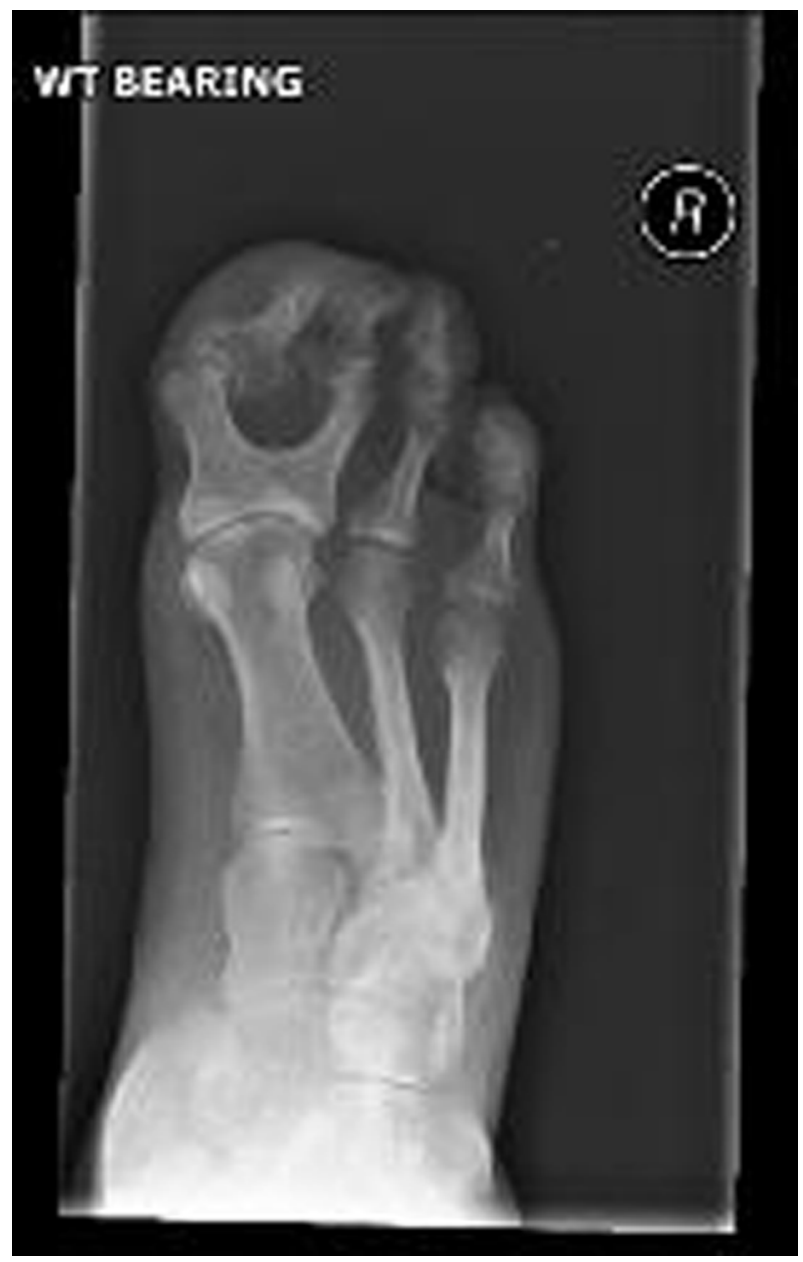

Figure 2 Radiograph of foot bones. 


\section{BMJ Case Reports}

Competing interests None.

Patient consent Obtained.

\section{REFERENCES}

1. Lamb D. The ball and socket ankle joint; a congenital abnormality. J Bone Joint Surg Br 1958;40-B:240-3.

2. Pistoi F, Ozonoff MB, Wintz P. Ball-and-socket ankle joint. Skeletal radiol 1987;16:447-51.

This pdf has been created automatically from the final edited text and images.

Copyright 2011 BMJ Publishing Group. All rights reserved. For permission to reuse any of this content visit http://group.bmj.com/group/rights-licensing/permissions.

BMJ Case Report Fellows may re-use this article for personal use and teaching without any further permission.

Please cite this article as follows (you will need to access the article online to obtain the date of publication).

Fernandes R. A rare case of a ball and socket ankle joint. BMJ Case Reports 2011;10.1136/bcr.10.2011.4919, Published XXX

Become a Fellow of BMJ Case Reports today and you can:

- Submit as many cases as you like

- Enjoy fast sympathetic peer review and rapid publication of accepted articles

- Access all the published articles

- Re-use any of the published material for personal use and teaching without further permission

For information on Institutional Fellowships contact consortiasales@bmjgroup.com

Visit casereports.bmj.com for more articles like this and to become a Fellow 